\title{
The effect of ageing on the fertilizer value of sludge from Botswana
}

\section{$*^{1}$ NGOLE VERONICA; ${ }^{2}$ TOTOLO OTLOGETSWE; ${ }^{3}$ MPUCHANE SISAI}

\author{
${ }^{1,2}$ Department of Environmental Science, ${ }^{3}$ Department of Biological Sciences, Faculty of Science, University of Botswana, \\ Private bag, 0022, Gaborone, Botswana
}

\begin{abstract}
This study was designed to characterize sludge of three different ages (36 months old, 3 months old and fresh sludge referred to as Type 1, Type 2 and Type 3 sludge respectively) in an endeavor to appreciate their suitability for use as manure for arable agriculture. Sludge properties including volatile solid and nutrient contents, concentrations of the heavy metals $\mathrm{As}, \mathrm{Cd}, \mathrm{Cr}, \mathrm{Co}, \mathrm{Cu}, \mathrm{Mn}, \mathrm{Pb}, \mathrm{Ni}$ and $\mathrm{Zn}$ as well as coliform population were determined. The concentrations of plant nutrients in the sludge followed the order Type 3 sludge $>$ Type $2>$ Type 1 sludge with nutrient content scores of 1.4, 2.1 and 2.6 respectively. Scores for potential leachability of heavy metals from the three sludge were $2.1,1.9$ and 2.3 for Type 1,2 and 3 sludge respectively, indicating that Type 2 sludge would release a higher concentration of heavy metals to the environment than the other two sludge types. The faecal coliform population in Type 3 sludge was higher than in Types 2 and 3 sludge with values of $5.6 \log _{10} \mathrm{MPN} / 10 \mathrm{~g}$ dry solid, $4.6 \log 10 \mathrm{MPN} / 10 \mathrm{~g}$ dry solid and $2.7 \log _{10} \mathrm{MPN} / 10 \mathrm{~g}$ dry solid respectively. These results revealed that the nutrient contents and heavy metal concentrations in the three sludge types may not hinder their application to soil for arable purposes but steps to allow for further pathogen reduction need to be taken to reduce health risks. @JASEM
\end{abstract}

Application of sludge (a residue of organic and inorganic solids derived from wastewater treatment) to soil is emerging as an economically and environmentally acceptable alternative to disposal through landfill and incineration (Stacey et al., 2001) because of the agronomic benefits associated (Veeresh et al. 2003; Lindsay and Logan 1998). It is practiced in several countries in Europe (Tlustoš et al. 2000), America (Krauss and Page 1997), Asia (Wong et al. 2001), and Africa (El-Naim and ElHousseini 2002, Snyman et al. 2000). Sludge production in Botswana especially in Gaborone City has increased recently as a result of the rapid rate at which the city is growing and the introduction of advanced wastewater treatment techniques. There is therefore a need to put in place appropriate disposal methods that will maintain a healthy environment and guarantee plant, animal, and human health.

In Botswana, in an effort to increase arable farming around major settlements, funding is available to small horticultural projects and the trend is to use sludge. Considering the fact that soils in semi-arid regions like Botswana are generally poor in physical conditions like water retention capacity, and are characterized by low plant nutrient status, commercial fertilizers are required for any reasonable agricultural production. Whereas these fertilizers mainly serve to improve the plant nutrient status of the soil, sludge in addition to this, improves soil physical, chemical and biological properties (Lindsay and Logan 1998; Veeresh et al., 2003; Pascual et al., 1997). Using sludge as manure could therefore improve the condition and fertility of these arid soils, while simultaneously converting waste into a resource. Its use as manure for the production is however constrained by five of its constituents namely pathogen load, heavy metal concentrations, plant nutrients contents, organic matter content usually measured as volatile solids, and the concentrations of toxic organic compounds (US EPA, 1999).

Previous studies on sludge from the Gaborone City Council wastewater treatment plant (Ngole et al. 2006) concentrated on the survival of sludge bornecoliforms in different soils. No study has evaluated the fertilizer value of this sludge even though it is currently being used as manure by some farmers. This study was designed to evaluate the quality of the sludge produced at this plant in terms of its heavy metals concentrations, pathogen load, nutrient contents and other physico-chemical and biochemical properties that may affect its fertilizer value. The effect of age on the fertilizer value was also investigated.

\section{MATERIALS AND METHODS}

Sludge Sampling: Three types of sludge differentiated by their ages ( 36 months old, 3 months, fresh sludge from the drying beds henceforth referred to as Type 1, Type 2 and Type 3 sludge respectively) were used in this study. Samples of Type 1 and Type 2 sludge were collected from the respective sludge piles around the treatment plant. Three piles each of Type 1 and Type 2 sludge were divided into 8 sections and 2 samples collected from each section. Samples of each sludge type were manually homogenized to form a composite sample which was representative of the particular sludge type. Type 3 sludge samples were collected from sludge drying beds which were about to be emptied onto the sludge piles. Sludge sampling from the drying beds was guided by methods described in US EPA (1999)

\footnotetext{
*Correspondence: E-mail: NGOLEVM@mopipi.ub.bw
} 
where each drying bed is divided into 4 and 2 samples collected from the centre of each quarter, and at the centre of the bed.

Sludge Analyses: Sludge properties including solid content (SC), $\mathrm{pH}$, electrical conductivity (EC), total dissolved salts (TDS), cation exchange capacity (CEC), exchangeable bases $\mathrm{K}, \mathrm{Na}, \mathrm{Ca}, \mathrm{Mg}$, organic matter (OM), total Kjeldahl nitrogen (TKN), available nitrogen $\left(\mathrm{NH}_{4}-\mathrm{N},+\mathrm{NO}_{3}-\mathrm{N}\right)$, and Olsen $\mathrm{P}$ were determined according to methods described by van Reeuwijk (1993) and USDA (1996). Chloride, sulphate, carbonate and bicarbonate concentrations were determined in the saturation paste extracts of each sludge sample (USDA (1996) whereas the volatile solid content (VS) was determined by ashing at $550^{\circ} \mathrm{C}$ in a muffle furnace (Standard Methods for the Examination of Water and Wastewater 1996).

The US EPA's 1992 toxicity characteristic leaching procedure (TCLP) was used to determine the concentrations of the potentially leachable fraction of heavy metals $\mathrm{As}, \mathrm{Cd}, \mathrm{Cr}, \mathrm{Co}, \mathrm{Cu}, \mathrm{Mn}, \mathrm{Pb}, \mathrm{Ni}$ and $\mathrm{Zn}$ in the three sludge types. Each sludge sample was also extracted with aqua regia $\left(3 \mathrm{HCl}+\mathrm{HNO}_{3}\right)$ solution as described by Tokalioğlu et al., (2003) to determine the pseudo-total concentrations of these heavy metals. A SpectraAA Varian 220 FS flame atomic absorption spectrometer (FAAS) with deuterium background correction and equipped with a graphite furnace component (GTA 10) was used to determine the concentration of heavy metals in the different extracts. Enumeration of total coliforms (TC) and faecal coliforms (FC) in the different sludge types was done using the multiple tube fermentation procedure as described by US EPA (1999). A bioMérieux Sa API 20 E identification system, Software Package and Analytical Profile index Library were used to identify the different enteric bacteria contained in each type of sludge.

To compare the fertilizer value of the three sludge types, their properties were given scores on a scale of $1-3$ with those scored as 1 indicating the lowest fertilizer value and 3 the highest. With regards to nutrients, the sludge type with the highest value for the specific nutrient was given the highest score (3) and that with the lowest value the lowest score (1). Considering the fact that a high concentration of metals and coliforms in the sludge would degrade its fertilizer value, the sludge type with the highest concentration of each heavy metal as well as faecal coliform was scored 1 and that with the lowest concentration scored 3 . These scores were averaged and used to compare the fertilizer value of the three sludge types.

Ngole Veronica; Totolo Otlogetswe; Mpuchane Sisai

\section{RESULTS AND DISCUSSIONS}

Sludge Properties: Whereas the solid content of the sludge increased with age (Type $1>$ Type $2>$ Type 3 ), the VS and OM contents decreased (Type $3>$ Type $2>$ Type 1 ) as indicated by the values in Table 1. The higher content of solid materials in Type 1 sludge could be attributed to its age because it had been exposed to the desiccating action of the sun for a longer period than either of Type 2 or Type 3 sludge. The longer period of exposure also account for the lower values of OM and VS content in this sludge. Reduction in OM content of sludge with age has also been reported by Leifeld et al., (2001) and is attributed to the processes of humification and mineralization of the sludge-derived OM (Sollin et al., 1996). These processes convert organic material in the sludge to inorganic forms resulting in a reduction of the amount of $\mathrm{OM}$ accumulated with age. Volatile solid content in sludge correlates directly with the amount of OM contained in the sludge (US EPA, 1984). The observed reduction in OM with age may therefore explain the reduction observed in the VS content of the sludge with age.

Type 1 sludge was more acidic $(\mathrm{pH}=5.4)$ than both Types 2 and 3 sludge with $\mathrm{pH}$ values of 7.1 and 6.6 respectively. Microbial decomposition of $\mathrm{OM}$ results in the production of organic acids among other compounds (Veeresh et al. 2003). The lower $\mathrm{pH}$ value obtained for Type 1 sludge compared to Type 2 and Type 3 sludge could be attributed to the accumulation of organic acids produced during the decomposition of the OM contained in the sludge. A lower sludge $\mathrm{pH}$ implies an increase in the tendency for ionic compounds to go into solution and consequently, a higher EC. Values for EC and TDS followed the order Type $1>$ Type $2>$ Type 3 sludge, indicating an increase in EC and TDS with age of sludge. This pattern correlates negatively with the values for $\mathrm{pH}(r=-0.90)$ and OM content $(r=-0.94)$ of the sludge. About $80 \%\left(R^{2}=0.81\right)$ of the changes observed in the EC of the three sludge types could therefore be explained by changes in $\mathrm{pH}$ and $\mathrm{OM}$ content in the sludge. According to EL-Naim \& ELHouseini (2002), OM humification results in the formation of carboxyl and phenolic functional groups onto which cations could be adsorbed. Due to the availability of nutrients, microbial activities are more vigourous in fresh than in old sludge, resulting in a faster rate of $\mathrm{OM}$ mineralization. More of the carboxyl and phenolic functional groups are likely to be present in the young sludge providing more sites onto which cations could be held thus explaining the higher value for CEC in Type 3 sludge (Table 1). 
Table 1: Physico-chemical properties and nutrient content of the three sludge types

\begin{tabular}{|c|c|c|c|}
\hline Properties & $\begin{array}{c}\text { Type } 1 \text { sludge } \pm \\
\text { SD }\end{array}$ & $\begin{array}{c}\text { Type } 2 \text { sludge } \pm \\
\text { SD }\end{array}$ & $\begin{array}{c}\text { Type } 3 \\
\text { sludge } \pm \text { SD }\end{array}$ \\
\hline Solid content (\%) & $50.3 \pm 9.2$ & $47.7 \pm 5.8$ & $38.3 \pm 4.5$ \\
\hline VS (\%) & $23.0 \pm 4.3$ & $25.7 \pm 2.6$ & $29.2 \pm 10.2$ \\
\hline $\mathrm{pH}\left(\mathrm{H}_{2} \mathrm{O}\right)$ & $5.4 \pm 0.4$ & $7.1 \pm 1.1$ & $6.6 \pm 0.5$ \\
\hline $\mathrm{EC}(\mathrm{mS} / \mathrm{cm})$ & $4.4 \pm 0.4$ & $3.4 \pm 1.6$ & $3.2 \pm 1.6$ \\
\hline TDS (mg/l) & $3014.0 \pm 233.6$ & $2176.0 \pm 104.7$ & $2048 \pm 102.3$ \\
\hline $\mathrm{Cl}^{-}(\mathrm{mg} / \mathrm{kg})$ & $52.4 \pm 45.9$ & $51.6 \pm 16.4$ & $40.2 \pm 15.7$ \\
\hline $\mathrm{SO}_{4}^{2-}(\mathrm{mg} / \mathrm{kg})$ & $2744.1 \pm 121.8$ & $2716.3 \pm 167.9$ & $1533.5 \pm 92.2$ \\
\hline $\mathrm{HCO}_{3}^{-}(\mathrm{meq} / \mathrm{l})$ & $9.9 \pm 2.7$ & $29.4 \pm 4.4$ & $31.8 \pm 4.7$ \\
\hline $\mathrm{CEC}\left(\mathrm{cmol}_{\mathrm{c}} / \mathrm{kg}\right)$ & $89.0 \pm 3.2$ & $93.5 \pm 2.9$ & $128.1 \pm 7.8$ \\
\hline Exch. $\mathrm{Ca}\left(\mathrm{cmol}_{\mathrm{c}} / \mathrm{kg}\right)$ & $35.8 \pm 2.5$ & $46.9 \pm 0.8$ & $41.0 \pm 3.0$ \\
\hline Exch. K $\left(\mathrm{cmol}_{\mathrm{c}} / \mathrm{kg}\right)$ & $11.9 \pm 1.7$ & $16.5 \pm 1.2$ & $15.6 \pm 2.0$ \\
\hline Exch. $\mathrm{Mg}\left(\mathrm{cmol}_{\mathrm{c}} / \mathrm{kg}\right)$ & $37.9 \pm 3.2$ & $34.6 \pm 4.1$ & $64.2 \pm 5.3$ \\
\hline Exch. $\mathrm{Na}\left(\mathrm{cmol}_{\mathrm{c}} / \mathrm{kg}\right)$ & $19.1 \pm 2.0$ & $14.2 \pm 3.1$ & $13.0 \pm 1.0$ \\
\hline OM $(\%)$ & $23.1 \pm 12.8$ & $32.4 \pm 16.1$ & $41.0 \pm 14.6$ \\
\hline Olsen P (mg/Kg) & $7321 \pm 920$ & $7696.4 \pm 571$ & $9370.1 \pm 780$ \\
\hline TKN $(\%)$ & $3.4 \pm 2.1$ & $4.5 \pm 2.6$ & $5.5 \pm 2.0$ \\
\hline $\mathrm{NH}_{4}-\mathrm{N}(\mathrm{mg} / \mathrm{Kg})$ & $612.4 \pm 236.4$ & $614.4 \pm 267.9$ & $1369.4 \pm 357.8$ \\
\hline $\mathrm{NO}_{3}-\mathrm{N}(\mathrm{mg} / \mathrm{Kg})$ & $546.2 \pm 254.7$ & $636.5 \pm 227.2$ & $1654.3 \pm 253.8$ \\
\hline $\mathrm{Fe}(\%)$ & $2.9 \pm 0.4$ & $2.0 \pm 0.5$ & $0.8 \pm 0.4$ \\
\hline $\mathrm{Al}(\%)$ & $3.1 \pm 0.3$ & $3.0 \pm 0.1$ & $1.7 \pm 0.6$ \\
\hline
\end{tabular}

Sludge nutrient content: Due to the solubility of $\mathrm{K}$ and chloride compounds in water, more of these compounds are discharged with the treated effluent than are accumulated in the sludge derived from the wastewater, which may explain the low concentration of these ions in the sludge compared other organic manure. The concentration of exchangeable bases in the sludge followed the order $\mathrm{Ca}>\mathrm{Mg}>\mathrm{Na}>\mathrm{K}$ in Type 1 sludge whereas in Type 2 and 3 sludge, the orders were $\mathrm{Ca}>\mathrm{Mg}>\mathrm{K}>\mathrm{Na}$ and $\mathrm{Mg}>\mathrm{K}>\mathrm{Ca}>$ $\mathrm{Na}$ respectively (Table 1). Whereas the carbonates were not detectable, the concentrations of bicarbonate compounds decreased with increase in age of sludge (Table 1). The concentrations of Olsen P in the three sludge types followed the order Type 3 sludge $>$ Type 2 sludge $>$ Type 1 sludge, indicating a decrease with ageing of sludge. Whereas mineralization and leaching may account for the lower value of $\mathrm{P}$ obtained in Type 1 sludge, the higher content of OM in Type 3 sludge explains its higher $\mathrm{P}$ concentration since most of the $\mathrm{P}$ is not available for leaching. Phosphorus in young sludge exists mainly in the organic form, and becomes available for uptake or leaching only after it has been mineralized to inorganic forms (Maguire et al., 2001).

Total Kjeldahl nitrogen concentration as well as the concentrations of $\mathrm{NH}_{4}-\mathrm{N}$ and $\mathrm{NO}_{3}-\mathrm{N}$ was highest in Type 3 than in the other sludge types (Table 1). Decrease of TKN and both $\mathrm{NH}_{4}-\mathrm{N}$ and $\mathrm{NO}_{3}-\mathrm{N}$ with age of sludge is attributed to volatilization and leaching of nitrogen containing compounds from the sludge (Gilmour and Skinner 1999). More N would have been volatilized from Type 1 than from the other sludge types because of the longer period of exposure. Type 1 sludge was expected to have a higher concentration of $\mathrm{NH}_{4}-\mathrm{N}$ and $\mathrm{NO}_{3}-\mathrm{N}$ than the younger Types 2 and 3 sludge. This was however, not the case as the concentrations of $\mathrm{NH}_{4}-\mathrm{N}$ and $\mathrm{NO}_{3}-\mathrm{N}$ was higher in Type 3 sludge which is the youngest of the three sludge types. Studies carried out by Wong et al. (2001) showed that during anaerobic digestion of sludge, most of the $\mathrm{N}$ is converted to $\mathrm{NH}_{4}-\mathrm{N}$ which may justify its higher concentration in Type 3 sludge. In addition, $\mathrm{NH}_{4}-\mathrm{N}$ is rapidly volatized on mineralization while most of the $\mathrm{NO}_{3}-\mathrm{N}$ is easily leached out (Gilmour and Skinner 1999). These may therefore account for the lower values of $\mathrm{NH}_{4}-\mathrm{N}$ and $\mathrm{NO}_{3}-\mathrm{N}$ in the older Types 1 and 2 sludge than in Type 3 sludge.

Heavy metals concentrations in sludge: Both the values for Pseudo-total concentrations and the concentration of the leachable fraction of all metals analyzed were within the maximum acceptable concentrations stated by the Government of Botswana (2003), and the Permissible Utilization and Disposal of Sewage Sludge Edition 1, 1997 in South Africa (Snyman 2000) for sludge to be applied to soil. Heavy metal concentration in sludge is determined by the degree to which industrial wastewater has been mixed with the treated wastewater (European Commission, 2001). The relatively low level of industrialization in Botswana may explain the low values obtained for the pseudototal concentrations of the different heavy metals in the three sludge types. Among all the metals analyzed, values for both the pseudo-total concentration and the concentration of potentially leachable fraction of $\mathrm{Zn}$ were the highest in all three 
sludge types, whereas $\mathrm{Cd}$ had the lowest values (Table 2). Arsenic and $\mathrm{Cd}$ were not detected in the leachable fraction of all three sludge types. These metals are usually associated with industrial activities which are not common in Gaborone city thus explaining their low concentrations in the sludge. Not being able to detect these heavy metals in the leachable fraction of these sludge types could be indicative of the low risk posed by these sludge with regards to the addition of $\mathrm{Cd}$ and $\mathrm{As}$ in the environment

Table 2: Concentration of Heavy metal in the different sludge types

\begin{tabular}{lcccccc}
\hline Heavy metals & \multicolumn{5}{c}{ Concentrations in $\mathrm{mg} / \mathrm{Kg}$} \\
\cline { 2 - 7 } & \multicolumn{2}{c}{ Type 1 } & \multicolumn{3}{c}{ Type 2 } & \multicolumn{3}{c}{ Type 3 } \\
$\mathrm{nys}$ & leachable & Pseudo-total & leachable & Pseudo-total & leachable & Pseudo-total \\
$\mathrm{nd}$ & 3.9 & nd & 11.3 & nd & 14.8 \\
$\mathrm{Cd}$ & nd & 1.1 & nd & 1.5 & nd & 1.3 \\
$\mathrm{Cr}$ & 0.5 & 4.9 & 0.5 & 6.5 & 1.0 & 4.8 \\
$\mathrm{Cr}$ & 1.1 & 4.4 & 0.9 & 5.8 & 1.3 & 5.3 \\
$\mathrm{Cu}$ & 2.4 & 110.8 & 1.6 & 115.9 & 0.8 & 63.2 \\
$\mathrm{Mn}$ & 10.2 & 251.1 & 10.9 & 270.3 & 10.3 & 114.1 \\
$\mathrm{Ni}$ & 5.3 & 17.6 & 6.1 & 22.8 & 6 & 12.9 \\
$\mathrm{~Pb}$ & 7.9 & 228.6 & 7.2 & 295.5 & 6.9 & 209.7 \\
$\mathrm{Zn}$ & 125.0 & 341.0 & 172.0 & 400.0 & 90.7 & 346.6 \\
\hline \multicolumn{7}{c}{ nd }
\end{tabular}

Less than $40 \%$ of the concentration of each heavy metal analyzed was leachable (Figure 1). Binding of heavy metals by OM contained in sludge (McBride et al.1997) may explain the low leachability of the heavy metals in Type 1 sludge. This is further justified by the scores for metal leachability which were 2.1, 1.9 and 2.3 for Types 1, 2, and 3 sludge respectively. Heavy metals adsorbed onto $\mathrm{OM}$ are desorbed on mineralization of the OM, which may explain the higher concentrations of leachable fraction of heavy metals in Type 2 sludge. The desorbed heavy metals are susceptible to leaching, to which the lower values for the concentrations of leachable fraction of heavy metals in Type 1 sludge could be attributed. Apart from $\mathrm{Ni}$ which preceded $\mathrm{Zn}$ in the leachability in Type 3 sludge, potential leachability of heavy metals in the three types of sludge followed the order $\mathrm{Zn}>\mathrm{Ni}>\mathrm{Cr}>\mathrm{Co}>\mathrm{Mn}>$ $\mathrm{Pb}>\mathrm{Cu}$ (Fig 1).

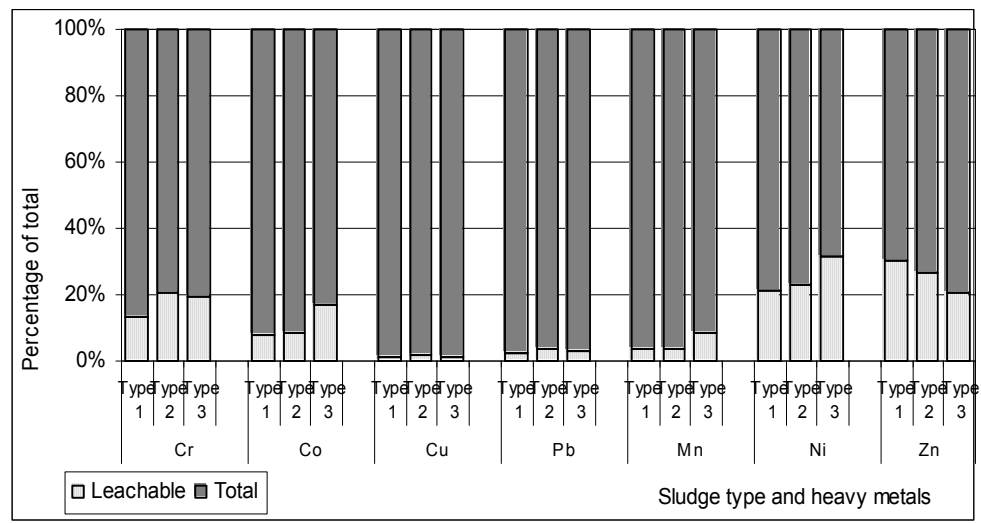

Fig 1: Distribution of heavy metal concentrations in the different sludge types between leachable and total fractions

Total and faecal coliform population in sludge: The suitability of faecal coliform as an indicator for faecal contamination has been documented by Windfield and Groisman (2003). Though TC are present in most environmental substrates, FC inhabits mostly the lower intestine of warm-blooded animals which justify their presence in the three sludge types. The population of both total coliforms (TC) and faecal coliforms (FC) in Type 3 sludge was higher than that in Type 2 sludge which was itself higher than the population in Type 1 sludge (Figure 2). These results indicated a decrease in coliform population with increase in the age of the sludge. Outside the host environment, coliforms are exposed to environmental factors such as temperature and moisture fluctuations, and the disinfecting and desiccating effects of the sun which all have a negative effect on their survival. 


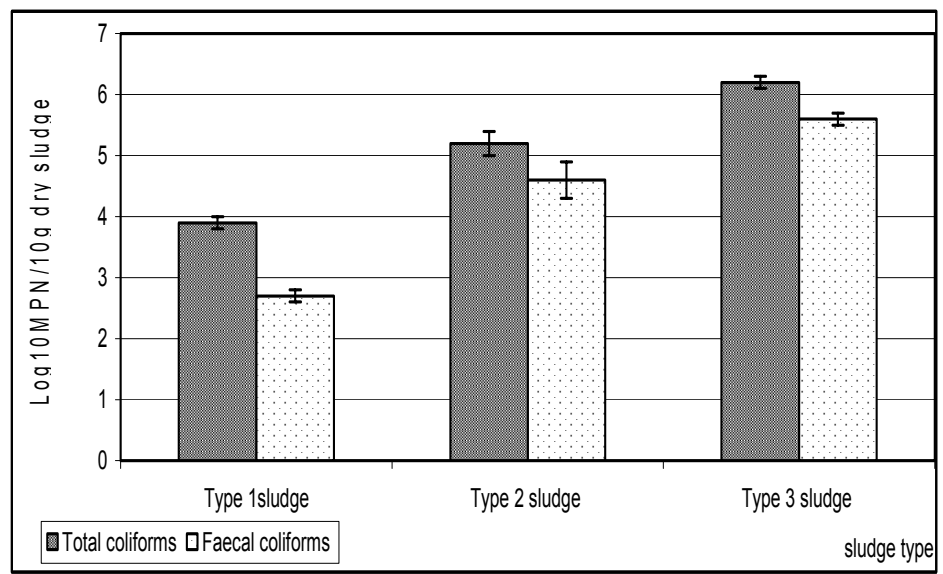

Fig 2: Total and faecal coliforms contained ion the three sludge types

A longer period of exposure to these factors as was the case with Type 1 sludge compared to Types 2 and 3 sludge explains the decrease in coliform population with increase in age of sludge. According to Epstein (1998) faecal coliform survival period in soil ranges from $12-268$ days. The numbers indicated especially in Type 1 sludge which was over 3 years old could have resulted either from recontamination from sludge dust and leachate or regrowth of these organisms or both. Enterobacteria identified using API 20 E analyses included Enterobacter cloaca and Enterobacter sakazakii in Type 1 sludge, Klebsiella pneumoniae, and Escherichia coli I (an API- group differentiated on the basis of biochemical reactions), in the Type 2 sludge, and Klebsiella pneumoniae, Escherichia coli I, Enterobacter cloaca, Enterobacter sakazakii, Yersinia intermedia, and Enterobacteria aerogenes in Type 3 sludge.
Agronomic value of the three sludge types: Plant macronutrients contained in all three sludge types were comparable with those of other commonly used animal manures but the $\mathrm{K}$ content as expected of sludge (Brady and Weil, 1998) was lower (Table 3). The advantage of using sludge over these organic manures stems from the fact that it has a slower rate of organic nitrogen mineralization (Gilmour and Skinner, 1999). Nitrogen contained in sludge could therefore be available over a longer period of time thus reducing the frequency of application and potential risk of surface and groundwater contamination. In addition sludge contains $\mathrm{Fe}, \mathrm{Al}$, and $\mathrm{Ca}$, which form insoluble phosphates (Maguire et al., 2001). The risk of surface and groundwater contamination with $\mathrm{P}$ from sludge-amended soils is lower than from soils amended with other organic manures.

Table 3: A comparison of the nitrogen, phosphorus, and potassium values of various organic manures with that of Types 1, 2 and 3 sludge.

\begin{tabular}{llll}
\hline Kind of Manure & Nitrogen (\%) & Phosphorus (\%) & Potassium (\%) \\
\hline Type 1 sludge & 3.4 & 0.7 & 0.5 \\
Type 2 sludge & 4.5 & 0.8 & 0.7 \\
Type 3 sludge & 5.5 & 0.9 & 0.6 \\
Poultry manure* & 4.4 & 2.1 & 2.6 \\
Dairy cow* & 2.4 & 0.7 & 2.1 \\
Horse* & 1.4 & 0.4 & 1.0 \\
Sheep/goat* & 3.5 & 0.6 & 1.0 \\
\hline \multicolumn{5}{c}{ *Source: Brady and Weil, (1998) }
\end{tabular}

Scores obtained from the plant nutrients contents and other parameters like SC, $\mathrm{pH}, \mathrm{EC}$ and $\mathrm{CEC}$ that may affect sludge fertilizer value indicated that Type 1 sludge had a higher fertilizer value than Types 1 and 2 sludge (Figure 3). However, with the values for exchangeable sodium percent (ESP) being $21.5 \%$,
$15.2 \%$ and $10.1 \%$ for Type 1 , Type 2 and Type 3 sludge respectively, salinity problems may be encountered especially if Type 1 sludge is used. With regards to the VS and OM contents as well as the population of coliforms, Type 1 sludge had a better fertilizer value than the other sludge types (Fig 3). 


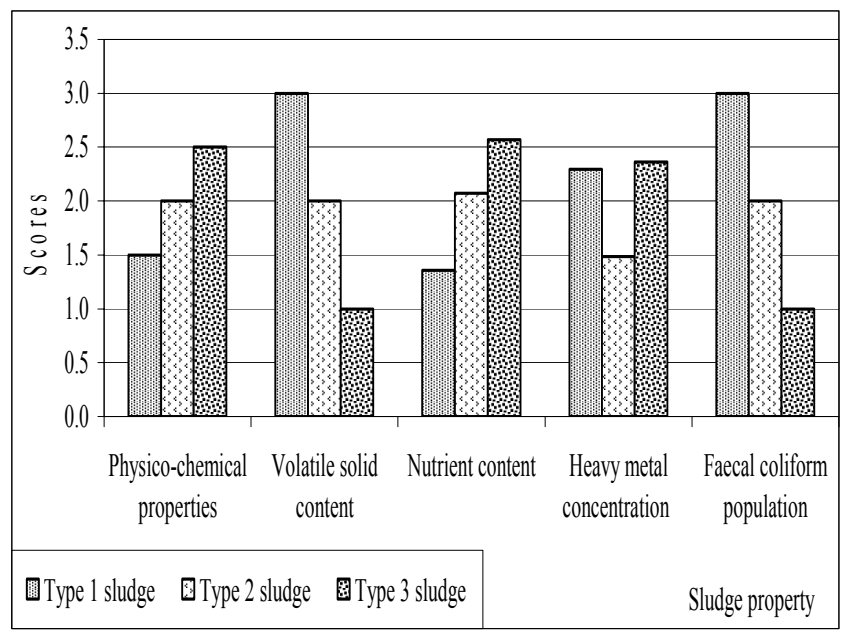

Fig 3: Fertilizer value of the three sludge types with regards to their constituents

If a considerable time is allowed between when the sludge is applied to the soil and when seeds are sown, the fertilizer value of the sludge may be improved. A previous study by Ngole et al., (2006) recommended that a minimum period of 90 days be allowed between when sludge is applied to soil and when seeds are sown in the soil to allow for further pathogen reduction. The specific period is however determined by the soil type on which the sludge is applied (Ngole et al, 2006).

The potentially leachable fraction of heavy metals contained in the sludge indicated the fertilizer value to be Type 3 > Type 1 sludge > Type 2 sludge with scores of 2.3, 2.1 and 1.9 respectively. However, the pseudo-total concentrations indicated a similar value for Types 1 and Types 3 sludge with Type 2 sludge being of lower value (Figure 3 ). The fertilizer value of the three sludge Types followed the order Type 1 sludge $>$ Type $2>$ Type 3 sludge with mean scores of 2.2, 1.9 and 1.9 respectively. Though Type 2 sludge had the same mean score as Type 3 sludge, Type 2 sludge may be considered to be of better value because of its score for faecal coliform population.

\section{REFERENCES}

Brady, N. C., Weil, R. R (1998) Practical Nutrient Management. The nature and Properties of Soils $12^{\text {th }}$ Edition Prentice Hall New Jersey. P $612-$ 666.

El-Naim M. Abd and El-Houseini M. (2002) Environmental Aspects of Sewage Sludge Application in Egypt. 17 $7^{\text {th }}$ WCSS; $14-21$ August 2002. Thailand 50-1 -50-11.

Ngole Veronica; Totolo Otlogetswe; Mpuchane Sisai
Epstein, E. (1998) Pathogenic Health Aspects of Land Application. BioCycle Emmaus 39(9): 62 67.

European Commission (2001) Pollutants in Urban Wastewater and Sewage Sludge. 93 pg.

Government of Botswana (2003) Botswana National Wastewater and Sanitation Planning and Design Manual. Part 6. Department of Sanitation and Waste Management, Ministry of Environment, Wildlife and Tourism, Botswana.

Krauss, G. D., Page, A. L. (1997) Wastewater Sludge and Food Crops. Biocylce Emmaus, 38(4): 74 80

Leifeld, J., Siebert, S and Kögel-Knabner, (2001) Stabilization of Compost Organic Matter After Application to a Humus-free Sandy Mining Soil. Journal of Environmental Quality. 30: 602 - 607.

Lindsay B. J. and Logan T. J (1998) Field Response of Soil Physical Properties to Sewage Sludge. Journal of Environmental Quality 27:534 - 542.

Maguire, R. O., Sims, J. T., Dentel, S. K., Coale, F. J., and Mah, J. T. (2001) Relationship Between Biosolids Treatment Process and Soil Phosphorus Availability. Journal of Environmental Quality 30: 1023 - 1033.

McBride, M., Sauve, S., and Hendershot, W. (1997) Solubility control of $\mathrm{Cu}, \mathrm{Zn}, \mathrm{Pb}$ in contaminated soils. European Journal of Soil Science. 48: 337-346.

Ngole V. M., Mpuchane S., and Totolo O., (2006) Survival of Faecal Coliforms in Four Different 
Types of Sludge-amended Soils in Botswana. European Journal of Soil Biology (1n press)

Pascual, J. A, Garcia, C., Hernandez, T., Ayuso M., (1997) Changes in the Microbial Activity of an Arid Soil Amended With Urban Organic Wastes. Biology and Fertility of Soil 24(4): 429 - 434.

Snyman, H. G., Terblanche, J. S., van der Westhuizen, J. L. J., (2000) Management of Land Disposal and Agricultural Reuse of Sewage Sludge within the Framework of the Current South African Guidelines. Water Science and Technology 42(9), $13-20$.

Sollins, P., Homann, P., and Cadwell, B. A., (1996) Stabilization and Destabilization of Soil Organic Matter: Mechanisms and Controls. Geoderma $74: 65-105$.

Stacey, S., Merrington, G., Mclaughlin M. J., (2001) The Effect of Ageing Biosolids on the Availability of Cadmium and Zinc in Soil. European Journal of Soil Science 52: 313 - 321.

Standard Methods for the Examination of Water and Wastewater (1996) $19^{\text {th }}$ edn. American Puiblic Health Association/American Water Works Association/ Water Environment Federatiion. Washington DC, USA.

Tlustoš P., Balik, J., Pavlíková, D., Száková, J., Kaewrahum S., (2000) The Accumulation of Potentially Toxic Elements in Spinach Biomass Grown on Nine Soils Treated with Sewage Sludge. ROSTLINNÁ VÝROBA, 46, (1): 9 16.

Tokalioğlu, S., Kartal, S., and Birol, G (2003) Application of a Three-Stage Sequential Extraction Procedure for Determination of Extractable Metal Contents in Highway Soils. Turkish Journal of Chemistry 27, 333 - 346.
United States Department of Agriculture (USDA), (1996) Particle Size Analysis. Soil Survey Laboratory Methods Manual. Soil investigation Report No. 42 version 3.0, $31-111$.

US EPA (1992) Method 1311: Toxicity Characteristic Leaching Procedure.

US EPA (1984) Environmental Regulations and Technology: Use and Disposal of Municipal Sewage Sludge. EPA 625/10 - 84 - 003. 84 pages

US EPA (1999). Biosolids Generation, Use and Disposal in the United States. EPA $530-\mathrm{R}-99$ -00974 pages.

US EPA (1999) Method 1680: Faecal Coliforms in Biosolids by Multiple-Tube Fermentation and Membrane Filter Procedures. EPA No. EPA821-R-98-003.

Van Reeuwijk, L. P., (1993) Procedures for Soil Analysis, International Soil Reference and Information Centre (ISRIC) Technical paper, no. 9, ISRIC, $19 \mathrm{pp}$.

Veeresh, H., Tripathyl, S., Chaudhuri, D., Ghosh, B. C., Hart, B. R., and Powell, M. A. (2003) Changes in Physical and Chemical Properties of Three Soil Types in India as a Result of Amendment with Fly Ash and Sewage Sludge. Environmental Geology 43: 513 - 520.

Winfield D. M., and Groisman, E. A., (2003) Role of Nonhost Environments in the Lifestyle of Salmonella and Escherichia coli. Applied and Environmental Microbiology 69(7): 3687 3694.

Wong, J. C. W., Li, K., Fang, M., and Su D. C (2001) Toxicity Evaluation of Sewage Sludge in Honk Kong. Environment International 27: 373 - 380). 